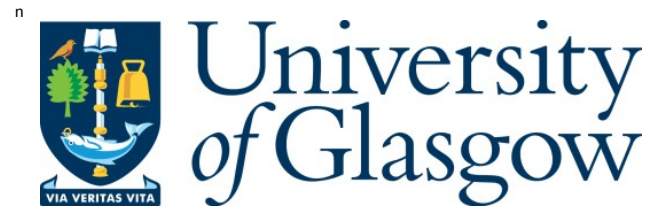

Ferguson, J., Sales de A guiar, T. R., and Fearfull, A . (2016) Corporate response to climate change: language, power and symbolic construction. A ccounting, A uditing and A ccountability Journal, 29(2), pp. 278-304.

There may be differences between this version and the published version. Y ou are advised to consult the publisher's version if you wish to cite from it.

http://eprints.gla.ac.uk/104962/

Deposited on: 14 A pril 2015

Enlighten - R esearch publications by members of the U niversity of Glasgow http://eprints.gla.ac.uk 


\title{
Corporate Response to Climate Change: Language, Power and Symbolic Construction
}

\author{
Authors:
}

\begin{tabular}{|c|c|c|}
\hline (*) Prof. Ferguson, John & $\begin{array}{l}(* *) \text { Dr. de Aguiar, } \\
\text { Thereza R. S. }\end{array}$ & Dr. Fearfull, Anne \\
\hline Phone: +44 (0)1334 462860 & $\begin{array}{l}\text { Phone: +44 (0) } 141330 \\
3993\end{array}$ & Phone: + 44(0)1382 384941 \\
\hline $\begin{array}{l}\text { Email: jf60@st- } \\
\text { andrews.ac.uk }\end{array}$ & $\begin{array}{l}\text { Email: } \\
\text { Thereza.SalesDeAguiar@gl } \\
\text { asgow.ac.uk }\end{array}$ & $\begin{array}{l}\text { Email: } \\
\text { a.fearfull@dundee.ac.uk }\end{array}$ \\
\hline $\begin{array}{l}\text { Professor of Accounting } \\
\text { School of Management } \\
\text { University of St Andrews } \\
\text { The Gateway } \\
\text { North Haugh } \\
\text { St Andrews } \\
\text { Fife } \\
\text { KY16 9RJ } \\
\text { UK }\end{array}$ & $\begin{array}{l}\text { Lecturer in Accountancy } \\
\text { University of Glasgow } \\
\text { Adam Smith Business School } \\
\text { (South), room } 682 \\
\text { University Avenue } \\
\text { Glasgow } \\
\text { G12 8QQ, UK }\end{array}$ & $\begin{array}{l}\text { Senior Lecturer in Management } \\
\text { School of Business (Accounting } \\
\text { and Finance) } \\
\text { University of Dundee } \\
1 \text { Perth Road } \\
\text { Dundee } \\
\text { DD1 4HN, UK }\end{array}$ \\
\hline Author's biography: & Author's biography: & Author's biography: \\
\hline $\begin{array}{l}\text { John's research takes an } \\
\text { interdisciplinary approach to issues } \\
\text { of corporate governance and } \\
\text { accounting. Before joining the } \\
\text { University of St Andrews, John has } \\
\text { held academic posts at the } \\
\text { University of Dundee and the } \\
\text { University of Strathclyde }\end{array}$ & $\begin{array}{l}\text { Thereza's research background } \\
\text { is on corporate social } \\
\text { responsibility with main focus } \\
\text { on social and environmental } \\
\text { accounting and climate change. } \\
\text { Currently, Thereza is full time } \\
\text { lecturer in accountancy and has } \\
\text { had previous experience in } \\
\text { working in the power industry. }\end{array}$ & $\begin{array}{l}\text { Anne's research interests are } \\
\text { within the broad field of } \\
\text { Organizational Sociology with a } \\
\text { focus on issues related to } \\
\text { accountability, critical } \\
\text { management and identity, } \\
\text { structure and agency. Before } \\
\text { joining the University of Dundee, } \\
\text { Anne has held posts at the } \\
\text { University of St. Andrews, } \\
\text { UMIST and the University of } \\
\text { Leeds. }\end{array}$ \\
\hline
\end{tabular}

\section{(*) First author (**) Corresponding author}




\title{
Corporate Response to Climate Change: Language, Power and Symbolic Construction
}

\begin{abstract}
Purpose - The objective of this paper is to explore corporate communications related to climate change in both a voluntary and mandatory setting. Adopting a critical perspective, the paper examines how companies who participated in the voluntary UK Emissions Trading Scheme (UK ETS) and the UK Government's mandatory Carbon Reduction Commitment Energy Efficiency Scheme (CRC) positioned themselves within the climate change debate. In particular, our analysis draws attention to how companies, through their communicative practice, helped to constitute and reproduce the structure of the field in which they operate.
\end{abstract}

Design/Methodology/Approach - A context-sensitive discursive analysis of 99 standalone reports produced by companies participating in the UK ETS and CRC over a nineyear period. Our analysis is informed by Thompson's (1990) depth-hermeneutic framework, which mediates the connection between linguistic strategies and the institutional field.

Findings - Our analysis suggests that companies tended to adopt particular linguistic strategies in their communications related to climate change. For example, the strategy of 'rationalization' was employed in order to emphasise the organisational 'opportunities' resulting from climate change; in this sense, companies sought to exploit climate crises in order to advance a doctrine that endorsed market-based solutions. A noteworthy finding was that in the mandatory CRC period, there was a notable shift towards the employment of the strategies that Thompson (1990) refers to as 'differentiation' - whereby companies attempted to displace responsibility by presenting either government or suppliers as barriers to progress.

Originality/Value - This paper explores how disclosure on climate change evolved while organisations participate in voluntary and compulsory climate change initiatives. In this respect, the analysis is informed by the social and political context in which the disclosure was produced.

Keywords - Discourse, Environmental Disclosure, Emissions Trading Scheme, Climate Change, Ideology.

Paper type - Research paper 


\section{Corporate Response to Climate Change: Language, Power and Symbolic Construction}

\section{Introduction}

Since the 1970s, the growth of environmental activism, increasing evidence of climate change and the unfolding of environmental policy has forced companies to respond to an escalating environmental agenda. Business responded in a number of ways, ranging from aggressive resistance, lobbying and challenging the science of climate change in the 1980s and early 1990s (Böhm and Dabhi, 2009; Giddens, 2009; Kolk et al., 2008), to an arguably more engaged position which has seen companies attempt to "reconstruct themselves as responsible stewards of the environment” (Levy and Egan, 2003; p.804). A number of studies have highlighted how companies are attempting to reconstruct themselves by framing the debate on their own terms through "how they talk and write about the natural environment” (Milne et al., 2009; p.1212 but see also Buhr and Reiter, 2006; Kolk and Pinkse, 2004; Laine, 2005, 2010; Nyberg and Wright, 2012; Spence, 2007; Spence, 2009; Spence and Thomson, 2009; Tregidga and Milne, 2006). In this sense, as Spence (2007; p.857) argues, the language used by companies through their corporate communications can be viewed as both constitutive, by "providing conceptual guidance for actions [and] policy prescriptions" and hegemonic, through the cultivation of "ideological consent” which serves dominant groups within society (Spence, 2007; p. 857).

This paper builds upon recent studies that have taken a discourse-based approach to the analysis of corporate communications related to the environment (Laine, 2005, 2009, 2010; 
Mäkelä and Laine, 2011; Milne et al., 2009; Nyberg and Wright, 2012; Spence, 2007; Spence and Thomson, 2009; Tregidga and Milne, 2006). In particular, this study is concerned with the climate change agenda and how companies who participated in the voluntary UK Emissions Trading Scheme (UK ETS) and the mandatory Carbon Reduction Commitment Energy Efficiency Scheme (CRC) represent it. More specifically, the paper addresses the following research question: do the linguistic strategies employed by companies in the course of their "position takings" within the climate-change debate change following a transition from a voluntary to a mandatory setting? (Sonnett, 2009; p.700). In this sense, this paper is concerned with the ideological role played by language in the construction and reproduction of power relations. An important aspect of our analysis is that we combine micro-level linguistic analysis with an examination of the broader macro factors that reside beyond the text (Grant et al., 2004). By analyzing how companies position themselves within a voluntary and mandatory setting, this study addresses the links between text and wider social and cultural processes (Vaara et al., 2010).

As a means of exploring further the characteristics of corporations' communications in relation to climate change, the remainder of the paper is structured as follows: in Section 2, we provide an overview of existing interpretive and discourse analytical approaches in accounting. This is followed, in Section 3, by an explication of Thompson's analytical framework, which informs the present study. In Section 4, we outline the research approach undertaken in the study, while Section 5 discusses the socio-historical context of the study; in particular, we draw attention to the institutional field and the context in which the UK ETS and CRC were designed and implemented. Section 6 provides an analysis of the 
linguistic strategies employed in corporate communications related to climate change. The final section provides a discussion of our findings and offers some conclusions.

\section{Organisational discourse and the environment}

As Milne et al. (2009; p. 1212) note, there is a rich tradition of content based text analysis in the area of social and environmental accounting. This important body of research has contributed to an understanding of "patterns of annual report disclosures", the emphasis placed on key issues and how organisational context has a bearing on disclosure activity (Milne et al., 2009; p. 1212). However, perhaps recognising the limitations of such contentbased work, a number of more recent studies concerned with corporate communications have employed discourse orientated and interpretative approaches (Buhr and Freedman, 2001; Chelli and Gendron, 2013; Laine, 2005, 2009, 2010; Mäkelä and Laine, 2011; Milne et al., 2009; Spence and Thomson, 2009).

The use of the term "discourse" has been applied in "a wide array of ways" (Alvesson and Karreman, 2000; p.1126); for example, Fairclough (1992; p.3) points out, "discourse" is a difficult concept, with many "conflicting and overlapping definitions formulated from various theoretical and disciplinary standpoints”. Nevertheless, according to Alvesson and Karreman (2000; p. 1126), it is possible to distinguish between two broad discourse analytical approaches: those which are concerned with text and talk in "social action contexts" and those concerned with how discourse can construct and maintain social reality. The former are concerned with "language in use" - talk and text as it occurs in social interaction (Grant et al., 2004; p.9). Such approaches tend to more 
ethnomethodological in nature, such as conversation analysis and interaction analysis (Grant et al., 2004). The latter are more "context sensitive" and are concerned with the "historical and social factors that reside beyond the text” (Grant et al., 2004; p.10). In keeping with recent studies in the area of social and environmental accounting, the present paper takes the latter approach. In particular, we aim to highlight how organisations constitute and reproduce the structure of the field in which they operate through their communicative practice, the prevalent linguistic strategies they employ, and the potential ideological role of those strategies. This is supported by a consideration of the wider context in which the communicative practice takes place - in particular, the voluntary and mandatory settings associated with the two periods of analysis.

\section{Discourse studies related to social and environmental reporting}

Existing research in this tradition has highlighted how corporations tend to emphasise the business case for dealing with environmental issues, articulating what is often referred to as a “win-win” scenario (Spence, 2007). For example, as Laine (2005; p.402) notes, companies disclosure related to sustainability tends to emphasise how "working towards sustainable development will not only solve social and environmental problems, but will bring further financial benefits” (see also, Laine, 2010). For Banerjee (2003) such “win-win” corporate discourse of sustainable development has “domination effects" (p.168) and ensures that “economic rationality determines ecological rationality” (p.174). Further, according to Banerjee (2003), Laine (2005; 2010) and Spence (2007), this discourse is ideological insofar as it constitutes meaning in the service of power - i.e. it presents corporations as "the liberating and protecting force that can ensure survival of the human race” in a way that serves their own economic interests (Banerjee, 2003; p.174). 
Moving beyond the employment of a "win-win" discourse, Milne, Kearins and Walton (2006), explore other linguistic strategies used in corporate communication related to sustainability issues; more specifically, they examine the use of "the journey metaphor". According to Milne et al. (2006), the use of this pervasive metaphor implies organisational transition and adoption. However, Milne et al. (2006) note that, for the companies analysed, there is little or no reference to the destination of the journey; in fact, some companies explicitly state that there is no destination. According to Milne et al. (2006), this “journey with no destination” (p.816) undermines any discussion of “desirable future states of living, and neatly sidesteps any debate about, or need to radically change course” (p.825). It is a linguistic strategy which serves to "further reinforce business as usual” (Milne et al., 2006; p.801), or as Tregidga et al. (2013) more recently put it, “through the journey metaphor, the business discourse on sustainable development simplifies, binds, defers, deflects, and redefines”.

In their analysis of a New Zealand business association and eight of its members, Milne et al. (2009; p.1211) take an “interpretive and discourse” approach, informed by Thompson’s (1990) schema for the typical linguistic modes of ideology. Their findings show how these organisations' communications reinforced (rather than challenged) notions of economic growth. Further, through a "rhetoric of practicality”, Milne et al. (2009; p.1235), highlight how these organisations helped construct the view that businesses are "doing” something about sustainability, while at the same time maintaining existing social relations through a rhetoric which supported "conventional business approaches” to the sustainability agenda (p.1241). The "rhetoric of practicality" is also framed in such a way that it maintains the 
assumption that: (i) the environment can be managed, and (ii) companies should be trusted to manage the process (see Tregidga et al., 2013). One implication of this framing is that "it promotes less government interference” (Tregidga et al., 2013; p.117).

The above studies highlight the potential role of language in shaping the wider understanding of environmental issues vis-à-vis business. As these studies have argued, it is through the common use of various metaphors and other linguistic strategies that companies maintain their privileged position within existing social relations. Nevertheless, despite providing these important insights, a number of shortcomings can be noted in relation to the above studies. First, none of the above studies (with the exception of Milne et al. 2009) take a linguistically informed approach to their analysis; they offer close critical readings of disclosure and draw attention to linguistic aspects - such as metaphor, but they are not informed by a formal analysis of language. Second, for most of the studies discussed above, the authors attempt to "read off" the constitutive or ideological aspects of the texts they analyse without considering the wider context in which the texts are produced and received. Again, Milne et al. (2009) are an exception - by drawing on Thompson's (1990) framework, they implement an approach for the analysis discourse previously developed and put forward by Ferguson (2007) and Ferguson et al. (2009).

In attempting to extend and further enrich this field of work, we draw on Thompson's (1990) analytical framework in order to inform our analysis of companies' disclosures on climate change. Drawing on this framework allows us to address some of the shortcomings in the extant accounting literature that we have alluded to above: in particular, the framework explicitly elaborates (i) a typology of linguistic strategies to inform the analysis 
of text, and (ii) a conceptual framework for the a wider socio-historical analysis. Therefore, an important aspect of Thompson's framework is that it is “context sensitive” - and stresses the importance of the historical and social factors that lie beyond the text (Thompson, 1990; see also Fairclough, 1992; Grant et al., 2004). By examining the linguistic strategies employed by companies in both a voluntary and mandatory reporting setting, we draw on Thompson's (1990) framework to link both the micro-level linguistic analysis with an examination of broader macro factors. An overview of this schema is provided in the following section.

\section{Thompson's Analytical Framework}

The work of sociologist John B. Thompson has informed a number of studies in the area of accounting; his Ideology and Modern Culture (Thompson, 1990) has been particularly influential within the genre (for example, Arnold, 1998, 1999; Chelli and Gendron, 2013; Ferguson et al., 2007; Ferguson et al., 2009; Francis, 1994; Milne et al., 2009; Oakes et al., 1994). In that work, Thompson (1990) developed a framework for the analysis of ideology as it appears in mass media forms. This framework incorporates important theoretical considerations on culture and the nature of mass media. A key aspect of Thompson's analysis was the recognition that the mass media environment engenders a distancing between the producer and recipient of "symbolic forms" or texts ${ }^{1}$. This concept led to the development of a “depth-hermeneutical” analytical framework that not only considered the structure of the text (or symbolic form), but also the wider socio-historical context of

\footnotetext{
${ }^{1}$ Thompson (1990; p.59) uses the term "symbolic forms" to refer to a "broad range of actions and utterances, images and texts, which are produced by subjects and recognized by them and others as meaningful constructs". These may include linguistic utterances, either spoken or inscribed, as well as visual images. For the purposes of the present study, we will simply refer to "text" or "texts", although we acknowledge that this represents only a subset of Thompson's (1990) broader classification.
} 
production and reception as well as the interpretation of producers' and recipients' understandings of a text (see Ferguson, 2007; Ferguson et al., 2009 for a more detailed overview of this framework). Thompson refers to this as a "tripartite” approach because it considers: (i) the production of text; (ii) the internal structure of text, and (iii) the reception of text. While the present study does not engage with the producers and recipients of standalone corporate environmental reports, we do draw on Thompson's framework in terms of addressing the social-historical dimensions of production and reception.

According to Thompson (1990; p.281), "symbolic forms do not subsist in a vacuum: they are produced, transmitted and received in specific social and historical conditions”. In outlining what he refers to as a conceptual framework for the analysis of the typical characteristics of social contexts, Thompson (1990) argues that social-historical analysis is required to "reconstruct" the social-historical conditions of production and reception (Thompson, 1990). Drawing heavily on the work of Bourdieu, part of Thompson's framework is concerned with fields of interaction and how individuals and institutions are differently positioned within fields according to the "quantities of resources or 'capital' available to them” (Thompson, 1990; p.282). The resources that can be drawn upon within fields can be classed in terms of different types of "capital” - i.e., economic capital, cultural capital and social capital. For Bourdieu (2004b; p.16) economic capital refers to the accumulation of financial resources, and "may be institutionalized in the form of property rights”. Cultural capital may take an embodied form, such as linguistic competence or dispositions, or may take an instutionalized form, such as educational qualifications (Bourdieu, 2004b; p.16). Social capital refers to “an individual's or individual group’s sphere of contacts” (Grenfell and James, 1998; p.21). Bourdieu (2004b) acknowledges that 
both cultural and symbolic capital have the potential, in certain instances, to be converted into financial capital.

Three recent studies in accounting, Chelli and Gendron (2013), Ferguson et al. (2009) and Milne et al. (2009) draw on a partial aspect of Thompson's framework, by placing greater emphasis on the linguistic/internal structure of the texts they analyse. While Thompson (1990) acknowledged that there are a wide range of approaches to the analysis of texts, he develops a schema incorporating some of the more common linguistic strategies of ideology or symbolic construction. A summary of these strategies or modes of ideology are presented in Table 1 below.

\section{Insert Table 1 around here}

Our application of Thompson's (1990) framework in this study draws on the recommendations of Ferguson (2007) and is similar in some respects to the approach taken by Milne et al. (2009). More specifically, by drawing on both mirco-level linguistic analysis and a consideration of wider "context sensitive" issues (Grant et al., 2004; p.10), our study partly addresses the criticisms which could be levelled at other studies in accounting that have drawn on Thompson's framework. In particular, through their emphasis on the textual aspect of Thompson's framework, both Ferguson et al. (2009) and Chelli and Gendron (2013) arguably commit what Thompson (1990) describes as the "fallacy of internalism" (see Ferguson, 2007 for a discussion of the "fallacy of internalism”). In taking a context sensitive approach, we draw on Thompson's (1990) framework to help us understand and explain the prevalent linguistic strategies employed in 
climate change related disclosures in the stand-alone reports of participants in the voluntary UK ETS and the mandatory CRC schemes. In so doing, we synthesize and extend from Thompson (1990) and Milne et al. (2009). Thus, our micro-level linguistic analysis is informed by an interpretation of the social-historical context in which these schemes were designed and implemented.

The following section delineates the research approach undertaken in the study.

\section{Materials and methods}

This study uses the two phases of an interpretative methodology suggested by Milne et al. (2009). The first phase refers to the analysis of the social-historical context in which the stand-alone reports were produced, circulated and received. In the first phase, we examined the context of two emissions trading schemes implemented in the UK: the UK ETS and the CRC. This part of the analysis is loosely informed by Thompson's (1990) conceptual framework for the analysis of the typical characteristics of social contexts. In this respect, this phase draws on the UK Government pronouncements on such policies, including public consultations, speeches and events, guidelines for participants in these schemes, news and media releases, presentations and audits. The analysis also includes an examination of the academic literature that focuses on these schemes.

The second phase involves a close interpretive analysis of the texts, drawing on Thompson's schema for the analysis of the typical strategies of symbolic construction (see Table 1) and informed by the analysis of the social-historical context. This phase requires 
an analysis of companies disclosures related to climate change in 99 stand-alone reports produced by the 24 companies that were direct participants in the UK ETS and also participate in the CRC (see Table 2). From this total, 63 reports were produced during the period 2001-2004, which includes the year before the UK ETS started (2001), the year that this scheme started (2002) and the two subsequent years (2003 and 2004). The analysis also includes 36 stand-alone reports produced in the year before the CRC started (2009) and the year it started (2010). This approach to our analysis allows us to consider the extent to which participation in voluntary or compulsory schemes has a bearing on the corporate discourse related to climate change.

\section{Insert Table 2 around here}

Corporate reports were downloaded from public sources such as organisations’ websites and the Corporate Register website. In our interpretative analysis, we sought to identify how the climate change agenda was being "talked” about by participating companies (Milne et al., 2009; p.1223). This approach required the coding of statements in the standalone reports, which we then organized into themes based on the linguistic strategies employed. As Thompson (1990; p.284) notes, the aim of discourse analysis within his framework is to consider the "articulated structure" of symbolic forms, acknowledging that while they are complex constructions they nevertheless “say something about something” (Thompson, 1990; p.284). As Chelli and Gendron (2013; p.191) note, the analysis of discourse is "based on the judgment, intuitive feelings, and interpretations of the researcher, while seeking to endow the exercise with a healthy dose of self-discipline”. While, as

Chelli and Gendron (2013; p.191) acknowledge, the coding process is necessarily 
subjective, it is “not arbitrary but guided by Thompson’s typology and an iterative and repeated analytical process”.

Our interpretive analysis is informed by a prior content analysis that was employed to capture the volume of linguistic strategies based on page number (Krippendorff, 1980) for each category of Thompson's typology. We adopt a content analysis approach based on Gray et al. (1995), which allows us to capture, in a preliminary way, a measure of the importance given to a topic - in terms of the space allocated to it in the report. In this way, we get a sense of the pattern of linguistic strategies employed in companies' communications related to climate change; this initial analysis provides the basis of a more in-depth interpretive analysis. In order to undertake the content analysis, a set of decision rules (Hackston and Milne, 1996) were produced in order to guide the coding process (available from the authors upon request). An analysis of the text classification in Thompson's typology was undertaken twice by a coder, with an interval of a week between the two rounds. The results between the two rounds were compared in order to identify and sort any discrepancies. A second coder/co-author independently analysed the statements extracted from the reports. These analyses were then compared and discrepancies checked, thus enabling sufficient consistency in the coding of the empirical data (Milne and Adler, 1999).

The following section describes the results from the first of these two phases of analyses. 


\section{The Socio-Historical Context of UK Climate Change Policy}

Giddens (2009; p.1) rather succinctly sums up climate change as follows:

"It refers to the fact that the greenhouse gas emissions produced by modern industry are causing the earth's climate to warm up, with potentially devastating consequences for the future”.

Policy interest in climate change has existed since at least the 1970s, when the UN became concerned about the potential of greenhouse gas emissions to create global warming and the associated environmental impact of this effect (Grubb et al., 1999). The policy process has been fraught with difficulty, given the reliance of some nations on industries deemed to have a greater impact on global climate change. From this contested arena, the term “sustainable development” emerged, promoted by the World Commission on Environment and Development (WCED, 1987) - and which, according to Bernstein (2000; p.470) “aimed to legitimate economic growth in the context of environmental protection”. In 1991, a more co-ordinated approach to tackling global climate change emerged, when the OECD countries, EU member states and other economies in transition met under UN auspices and established the UN Framework Convention on Climate Change (UN FCCC). This was ultimately signed at the Rio Earth Summit in June 1992 - again, as Bernstein (2000) notes, with an emphasis on "growth", this process strengthened and "further legitimated the link to liberal economics”.

Early attempts at addressing climate change provide an insight into an escalating climate policy issue, being addressed at both national and supranational levels. However, it is important to note that, up until this point, the position of "a considerable number of large multinational companies” was to oppose policy recommendations or to lobby national 
governments to enact business friendly policies (Kolk and Pinkse, 2004). It was only with the Kyoto Protocol in 1997, where countries agreed to legally reduce greenhouse gas emissions that companies (perhaps surprised by government support for Kyoto) began to stop their opposition to global climate change related policies. While companies and industries in different social and economic contexts reacted differently, the business response to Kyoto has arguably been to adopt "higher disclosure indexes” (Freedman and Jaggi, 2005; p.215).

The following section discusses these strategies in the context of two emergent policies, in the form of emissions trading schemes in the UK: the UK ETS and CRC.

The context of the UK Emissions Trading Scheme ${ }^{2}$

In 1998, a government sponsored report published by Lord Marshall, then Chairman of British Airways (Marshall, 1998) suggested that the use of economic instruments would help alleviate the damaging effects of global climate change. The report proposed a tax on energy use and a trading scheme to address greenhouse gas emissions. In 1999, the UK Government began to operationalise these suggestions and implemented a tax in 2001 in the form of a Climate Change Levy based on energy use (National Audit Office - NAO, 2004). The application of the Climate Change Levy was an important mechanism for emissions control. However, the UK government felt it was necessary to complement this policy with an incentive to maintain organisational ‘competitiveness’ (HM Government, 2006). Consequently, in 2001, Climate Change Agreements were also implemented. These

\footnotetext{
${ }^{2}$ Four groups of organizations participated on the UK Emissions Trading Scheme, but this paper concentrates in only one of these four groups; the so-called "direct participants".
} 
agreements were established between the state and industry sectors, and provided an $80 \%$ reduction to the Climate Change Levy in return for emission reductions during 2002 to 2010.

However, the Department of Food, Environment and Rural Affairs (DEFRA) wanted to incentivize even better levels of emission reduction. Thus, 32 companies and other organisations (referred to henceforth as "direct participants”) bid voluntarily to reduce their emissions; in return $£ 215$ million was given as incentive over 5 years (2002 to 2006). Each direct participant received monetary incentives if they met their annual targets (see table 3). Annually, the reductions were converted into allowances. The direct participants could trade their allowances or save them for the future years. In addition, they could choose to reduce the emissions or buy allowances to cover exceeded emission (NAO, 2004). An accredited verifier was required to confirm companies’ measurement and assessment of emissions reductions.

\section{Insert Table 3 around here}

The UK ETS was designed initially by the UK Emissions Trading Group which was formed by influential UK businesses (Nye and Owens, 2008). The UK Emissions Trading Group was created by the Confederation of Business Industry (CBI) and the Advisory Council for Business and Environment (NAO, 2004; Von Malmborg and Strachan, 2005). Thus, the process of developing the UK Emissions Trading Scheme was premised on cooperation between business and Government (NAO, 2004). Arguably, the UK Government's attempt to reduce conflict with business led to the emergence of a scheme 
more favourable to business interests and influence. Indeed, according to Von Malmborg and Strachan (2005) and Nye and Owens (2008), the economic incentives offered by government were the principle reason companies participated in the Emissions Trading Scheme.

Nye and Owens (2008) have suggested that the participation in the UK ETS was driven by symbolic politics (or a range of symbolic motives), which included the establishment of a network to influence legislation - perhaps indicative of the power and symbolic capital of industry and industry lobby groups (Bourdieu, 2004a). Interviews with business representatives and government officials participating in the UK Emissions Trading Group, suggested that organisations participated in the UK ETS in order to avoid compulsory legislation which could lead to them incurring high operational costs (Nye and Owens, 2008). Their voluntary participation in the UK ETS gave organisations the opportunity to self-regulate, incurring little economic risk and promoting "green impression management” (Nye and Owens, 2008). Again, drawing on Bourdieu's insights, the dominant positions of the direct participants in the UK ETS, and their control of different forms of capital, gave these actors the "power to mould and shape the "taken-for-granted" (doxic) elements within [the] field and therefore what is deemed to be legitimate within [the] field" (Lodhia and Jacobs, 2013; p.599).

A number of sources have highlighted the opportunistic behaviour of some direct participants, arguing that, in the first years of the UK ETS, targets were easily achieved (Böhm and Dabhi, 2009; de Aguiar and Bebbington, 2014; ENVIROS Consulting, 2006; 
NAO, 2004; Ney, 2008). The low trading volume of reductions certification during the first three years of the scheme also supports this observation. In its first year the UK ETS created 4.64 million tonnes of emission reduction, an excess of 3.85 million tonnes compared with the projected reductions (NAO, 2004).

\section{The context of the Carbon Reduction Commitment}

The origins of the Carbon Reduction Commitment hail from 2005 when the Carbon Trust ${ }^{3}$ highlighted the potential for emissions reductions in large non-energy intensive organisations (Carbon Trust, 2005; DECC, 2011; NERA Economic Consulting and ENVIROS Consulting, 2006). In 2006, the UK Government published the Energy Review, committing to reduce 1.2 MtC of carbon emissions per year in both large commercial organisations and the public sector (Department of Trade and Industry - DTI, 2006). In order to achieve this reduction, the UK Government planned to implement emissions trading in non-energy intensive organisations under the denomination of the CRC.

The CRC is the first mandatory scheme for non-energy intensive organisations (ENDS Environmental Data Service, 2009); therefore, compared to the UK ETS, the CRC involves a greater number of organisations ${ }^{4}$. As a cap-and-trade scheme, the CRC requires organisations to buy, in anticipation, allowances to cover annual emissions related to energy use (see Table 3). The CRC commenced in 2010 and participating organisations were only required to present a footprint report and annual report. By allowing participants

\footnotetext{
${ }^{3}$ http://www.carbontrust.com/about-us/our-board/

4 https://www.gov.uk/government/policies/reducing-demand-for-energy-from-industry-businesses-and-thepublic-sector--2/supporting-pages/crc-energy-efficiency-scheme
} 
to self-certify emissions, it could be argued that the CRC has taken a lighter approach than the UK ETS. The UK ETS required that a third party verify annual emissions, this requirement leading businesses to claim that the scheme was a "burden" (DECC, 2011). Even with the burden of verification removed, the design of the first CRC phase was considered complex, costly and difficult to implement (DECC, 2011). In response, the UK Government setup a consultation to simplify the scheme; the simplified version of the scheme came into force in 2013 (DECC, 2012; NAO, 2012).

The CRC aims to apply reputational, financial and civil penalties to participants (DECC, 2010). The information regarding the reputational penalty is in the form of a league table, which ranks the participants according to a number of parameters (Committee on Climate Change, 2010) ${ }^{5}$. Another purpose of the CRC was that it was to be used as a basis for the allocation of a financial incentive (revenue recycling), whereby the revenue from the trading market would generate around $£ 1$ billion per year. The intention of this approach was to recycle the revenue as an effective measure of energy efficiency. However, due to the on-going financial crisis, the UK government decided to designate the revenue to coverage of other public expenses (HM Treasury, 2010). The CBI have been immensely critical of the government's decision to abandon revenue recycling, and have persistently made calls to abandon the scheme on that basis (CBI, 2012). The CBI note that the incentive was one of the main reasons companies signed up to the scheme, and "without a proper incentive the scheme lacks credibility and has lost businesses’ trust” (CBI, 2011). Again, the social and economic capital represented by the CBI puts them in a position to

\footnotetext{
${ }^{5}$ The scheme administrator published league tables for the compliance years 2010/11 and 2011/12 (DECC, 2011). However, as part of the simplification of the CRC, the league table was abolished in 2013 and data on energy consumption and emissions will be disclosed instead (DECC, 2012).
} 
"mould and shape" the field of interaction (Lodhia and Jacobs, 2013; p.599; see also, Bourdieu, 2004a; Thompson, 1990).

\section{Summary of UK climate change policy context}

A range of different institutions and actors, encompassing the State, supra-international bodies, NGOs and industry, occupies the field of climate change policy in the UK. Within this field, these various institutions negotiate and manoeuvre for position, while "different forms of capital dominate and legitimate” the field (Oakes et al., 1998; p. 260). It is our contention that the field of climate change policy in the UK is dominated by the social and economic capital of industry: what Okereke (2008) refers to as the "liberal environmentalism compromise”. The ideological framing of climate change policy tends to emphasize market liberalism, which is, according to Tanner and Allouche (2011; p.5), "the most powerful ideology in terms of structural power” (see also Giddens, 2009). According to Giddens (2009; p.119), climate change policy has been particularly influenced by “fossil fuel lobbies, representing heavy industry, transportation, coal, oil and chemicals”, noting that industrial lobbies are "especially well organised and powerful”.

Further, this section has highlighted how, through the control of different forms of capital, industry and industry representatives helped shape both the UK ETS and CRC schemes (Lodhia and Jacbobs, 2013). In particular, the powerful voice and social capital associated with the CBI enabled them to influence the outcome of policy, in both schemes, in the interest of business. As noted, the CBI designed the UK ETS, while this powerful lobby group also took an active position in relation to the CRC in terms of the revenue recycling scheme. Moreover, it has been suggested in this section that the role of financial incentives 
were intrinsic to getting both schemes off the ground; again a further concession to business which also resulted, in the case of the UK ETS, a very generous amount of slack in terms of the allocation of allowances (Giddens, 2009; p.119).

Nevertheless, despite being shaped to a greater or lesser extent by industry, the CRC is still a mandatory requirement which incorporates reputational, financial and civil penalties to participants (DECC, 2010). In particular, one facet of the CRC scheme that had an important bearing on how organisations engaged with, managed and reported on their energy use, was the very public visibility of the league table - which was implemented in the early years of the CRC. As Power et al. (2009) note, how league tables are constructed or how an organisation performs on a league table is something which organisations have limited ability to contest. Further, because league tables represent "calculations of reputation...[they] have become governance mechanisms and routinized sources of risk to be actively managed”. In this respect, one could argue that this aspect of the CRC might have engendered greater levels of disclosure and discussion - with organisations perhaps seeking to provide, either implicitly or explicitly, justification for their performance.

Informed by the above assessment of the socio-historical context of climate change policy in the UK, the following section presents an analysis of climate change disclosures, drawing on Thompson's schema for the analysis of strategies of symbolic construction. 


\section{The characteristics of climate change disclosure}

In the first part of this section, we discuss some basic descriptive statistics in order to provide an overview of the data. The second part of this section provides an interpretative analysis of the data and delineates some of the major themes that were identified in that analysis.

\section{Descriptive Statistics}

This article analyses 99 stand-alone reports produced by companies participating in the UK ETS and CRC schemes (see Table 4). From this total, 56 reports were identified as employing the linguistic strategies typically associated with the operation of ideology (Thompson, 1990) in their narratives related to climate change. In some ways, such

coverage is to be expected, since stand-alone reports provide information on a vast range of social and environmental issues. Climate change represents one topic among these wider (albeit, related) issues; further, the topic of climate change also covers a wide-range of issues, including emissions data and targets descriptions - not all of which will take a narrative form (de Aguiar and Bebbington, 2014; de Aguiar and Fearfull, 2010).

\section{Insert Table 4 around here}

An examination of Table 4 shows that the linguistic strategies employed in relation to climate change were higher in the CRC period compared to the UK ETS period; 31 and 25, respectively. In terms of page coverage, there was also a higher proportion of narrative related to climate change in the reports produced during CRC period when compared to the 
UK ETS period. While the results show that the narrative reporting was more developed in the CRC period of analysis, this fact might not necessarily support the argument that mandatory reporting drives companies to make greater levels of disclosure and/or higher quality of disclosure (Deegan, 2002; Deegan and Rankin, 1997; Gray et al., 2014). We must urge caution with regard to the assumption that a mandatory reporting environment leads to higher quality (i.e. more accountable) forms of disclosure (Criado-Jimenez et al., 2008). For example, Bebbington et al. (2012), Criado-Jimenez et al. (2008) and Day and Woodward (2004) all point to the significant issue of non-compliance in a mandatory setting, or the employment of partial compliance and concealment strategies.

Table 5 shows the results of our analysis per mode of ideology and related linguistic strategies, as suggested by Thompson (1990). The results presented in Table 5 confirm that the employment of linguistic strategies was higher in the CRC period of analysis. Other changes in the pattern of linguistic strategies employed are also apparent. For example, there was a notable shift towards the employment of the strategies Thompson (1990) refers to as "universalization" and "differentiation”. In the case of universalization, there was an increasing trend for companies to identify a course of action that was of specific benefit to the companies themselves, as having a wider benefit to a range of stakeholder. In terms of differentiation, there was a notable shift towards companies seemingly trying to displace their responsibility for addressing climate change by identifying a range of other constituencies as also having responsibilities. A more in-depth interpretative analysis is provided further in this section, drawing attention to relevant contextual issues and illustrative examples. 


\section{Insert Table 5 around here}

Informed by our reading of the social and historical context of these schemes outlined and discussed above, three themes emerged from our analysis and we have typified them as follows: (i) Climate-crisis capitalism: an opportunity for market-based ideology, (ii) The policy debate unfolds: business is in control, and (iii) The chicken or the egg.

\section{Climate-crisis capitalism: an opportunity for market-based ideology}

Organisations used climate change disclosure to justify or legitimise their approach to dealing with the climate change agenda. It is our argument that the vast majority thus repositioned the perceived "threat” of global climate change into a market "opportunity”. We have classified such approaches as examples of rationalization. However, in the light of Thompson's point, that linguistic strategies often overlap, we would contend that such rationalisation also represents a strategy of dissimulation - by attempting to conceal or

obscure the underlying issue. While we do not regard the use of the word "opportunity" as euphemization, in the linguistic sense, it arguably represents an attempt to put a positive spin on climate change. Hence, Shell (2001; p.2) explicitly referred to climate change as a “real global challenge”, which nevertheless provided "new business opportunities”. Likewise, Ford (2004; p.7) recognised climate change as "a very serious threat" to their business, whilst also representing its “greatest opportunity as well”. Barclays (2009; p.18) were able to identify "business opportunities in the low carbon economy"

In spite of the 9-year span, and over both schemes, we continue to see in these narratives a perspective that overtly prioritizes business growth. It is our contention that the 
predominant organisational response to climate change is to simply view it as a means to achieve such growth. In doing so, direct participants tended to employ the dual linguistic strategies of rationalization and dissimulation, by playing down the underlying issue, presenting it as an opportunity and concealing and obscuring the social relations that they were trying to maintain.

Arguably, given the potentially disastrous consequences of global climate change, repositioning this phenomenon as an opportunity accords with of one of the key arguments made by Naomi Klein (2007) in her "Shock Doctrine” thesis. In particular, in describing what she terms “disaster capitalism”, Klein highlights how disasters have been used as marketing opportunities or as an opportunity to advance a particular (conservative) doctrine. This is perhaps best exemplified by Milton Friedman's comments in the wake of the Hurricane Katrina disaster in New Orleans:

"Most New Orleans schools are in ruins...as are the homes of the children who have attended them. The children are now scattered all over the country. This is a tragedy. It is also an opportunity." (Klein, 2007; p. 4-5)

The "opportunity" Friedman was alluding to was the introduction of a market-based, voucher system approach to schooling in New Orleans. As Klein (2007; p. 5) notes, while the repair of the levees and rebuilding of New Orleans took place at "glacial pace...the auctioning-off of New Orleans' school system took place with military speed and precision”. The opportunity that Friedman had identified was realised - "within 19 months...[the] New Orleans' public school system had been almost completely replaced by privately run charter schools". 
In what Bond (2011) describes as “Climate-crisis capitalism”, the predominant policy response to climate change mirrors the New Orleans example outlined above - i.e. the provision of market-based “solutions”, in particular, emissions trading. A number of critics have argued that the emergence of such schemes and the proliferation of environmental financial products are the result of an “ongoing neoliberal accumulation strategy" consistent with the phenomenon of "financialization" (McNicholas and Windsor, 2011; p.10).

In this respect, it is noteworthy that the vast majority of participants in both schemes not only outlined the opportunities presented by climate change, but also employed the linguistic strategy of rationalization, whereby a chain of reasoning was employed in order to express an explicit preference for a market-based approach to dealing with the climate change. As noted above, it has been suggested that one of the main motivations for participating in the UK ETS was to avoid compulsory legislation and to provide a mechanism for influencing government policy. Given this context, and as demonstrated by the narratives below, it is perhaps not surprising that the disclosures associated with the UK ETS participants tend to espouse a strategy of rationalization in favour of a market-based approach, which was usually described as more “cost effective”: For example, Ford (2004; p.24) state "We believe that this market-based approach can promote environmental improvements more cost-effectively than traditional regulations.” In a more developed chain of reasoning, BP (2004; p.37) express a preference for a market-based approach over a tax-based approach. They state:

"We believe that trading is one of the best policies to encourage businesses to reduce emissions, harnessing both the power of innovation and the flexibility of the market. Unlike a carbon tax, a cap- 
and-trade approach guarantees specified emissions reductions and creates a business incentive to reduce emissions through good management, efficiency, new technologies and improved processes.”(BP, 2004; p.37)

In the CRC period of the study, there is evidence of the same strategy of rationalization being employed by a large number of organisations; while the CRC is mandatory, it employs a market-based cap-and trade element, which corporations would arguably wish to maintain. For example, BP (2009; p.11) highlight how they have repeatedly called for action on climate change "preferably by creating a price for carbon through market mechanisms”. Rolls Royce (2010; p.9) highlight the cost-effectiveness of market based approaches, stating:

"We support the implementation of a well-designed and effective global emissions trading scheme. This will provide the means to make the most cost-effective greenhouse gas reductions within the required timescales.” (Rolls Royce, 2010; p.9)

Similarly, British Airways (2011; p. 9) argue that carbon trading is "the most cost effective tool to manage $\mathrm{CO}_{2}$ emissions from aviation”.

The rationalization apparent in these narratives, for market based approaches being the most cost-effective, was arguably accompanied by another strategy, referred to by Thompson (1990; p.60) as expurgation of the other - whereby other potential or existing external environmental policies/regulations were demonized for being "inefficient”. By transposing some of the terms used in the narratives, we can see that a tax-based approach is viewed by participating companies as [less] cost effective or as a [disincentive] to reduce emissions. In other words, we are beginning to see here the genesis of a blame-based approach, where the blame is levelled as far away from the organisations as possible. 
The policy debate unfolds: business is in control

Policy change initiatives related to climate change must be handled, in both planning and implementation stages, extremely carefully (Giddens, 2009). It is partly for this reason that the so called "win-win" scenario has dominated the business decision making model concerning environmental issues (Porter and Van der Linde, 1995a; Porter and Van der Linde, 1995b). This rationale reinforces a neoliberal logic in which responsible actions in a business context need to be justified on the grounds of economic efficiency. A recent and influential articulation of this logic has been espoused by Porter and Kramer (2011), who argue that "shared value... is a new way to achieve economic success". According to Porter and Kramer (2011) the "shared value” approach takes a long-term view of value creation by endongenising societal needs, which will lead ulitmately to companies innovating through the use of "new technologies, operating methods, and management approaches”.

While one could argue that Porter and Kramer's (2011) concern with the wider social context of business is laudable, there is scope for some scepticism. First, the approach is premised on businesses achieving economic success and thus, is underpinned by a "winwin” logic (see Laine, 2005; Milne et al., 2006). Second, Porter and Kramer (2011) argue that "government and civil society have often exacerbated the problem by attempting to address social weaknesses at the expense of business”. In other words, business should be in charge, since government interference (through regulation) only acts as an obstacle to companies who want to embrace the "shared value" approach.

In the context of global climate change, repositioning the threat of emissions' management (and the market mechanisms that come with it) as an opportunity not only flips the agenda, 
but also creates an illusion that global climate change is an issue on which business is in control (Milne et al., 2009). Further, a number of companies not only imply that they are in control of the agenda, but that wider stakeholder groups will benefit from their command of the situation (i.e., business control leads to a "win-win" scenario). This strategy is what Thompson (1990; p.61) refers to as universalization, whereby "institutional arrangements which serve the interests of some individuals are represented as serving the interests of all”. Again, this strategy was evident in both periods analysed. For example:

"Reducing greenhouse gas emissions proactively, transparently and affordably are key elements of our product development plans and are in line with the interests of our customers, shareholders and other stakeholders.” (Ford, 2004; p.61)

Disclosures during the UK ETS period of analysis perhaps indicate a greater deal of management hubris. In particular, disclosures tended to decry the efforts of national governments and supranational bodies for being inadequate compared to the great strides being made by business. As above, such statements arguably represent a combination of two strategies of symbolic construction: rationalization on the one hand, whereby the companies are reasoned to be cost-efficient, and expurgation of the other, whereby governments are represented as inadequate. For example Shell (2003; p.15) state:

"Governments have so far failed to agree a common international framework for action. This makes tackling the threat to climate harder and probably more expensive. Meanwhile, we continue to find practical ways to reduce our GHG emissions cost effectively and help our customers do the same.”

Similarly, Lafarge (2002; p.41) state:

“[...] Concerning the Kyoto targets, we acknowledge that they are not ambitious enough to solve the problem of climate change. It is a long-term problem and we expect more demanding objectives afterwards. This is one of the reasons for our involvement in the WWF's Climate Savers program which includes complementary voluntary targets.” 
More recent disclosures during the CRC period of analysis also drew attention to the inadequacies of other bodies, framed by the perceived failure of governments, post-Kyoto, to agree on criteria to tackle climate change. Arguably, this uncertain context provided organisations with an opportunity to construct a legitimating rationale for a voluntary business approach, which could deliver more immediate results and demonstrate a more “realistic” approach to carbon emissions. For example, Tesco (2009; p.3) state:

"Climate change remains one of our biggest strategic challenges. In the run-up to the Copenhagen climate summit in December 2009, while the world watched governments struggle to agree meaningful targets, we challenged ourselves to make a decisive contribution. [...]”

Similarly, Ford (2010; p.153) also alluded to a perceived failure of governments to agree on policy or introduce legislation, while crediting themselves with moving the agenda forward. They state:

“...During 2009, the climate change policy landscape continued to evolve. The recession put economic issues at the top of government and public agendas. The Copenhagen summit fell short of producing a binding global agreement, and climate change legislation did not pass the U.S. Congress. In the United States and elsewhere, we continue to actively advocate for comprehensive policy approaches that will provide a coherent framework for greenhouse gas (GHG) emission reductions, so that companies can move forward in transforming their businesses with a clear understanding of their obligations..."

Lafarge (2010; p.11) employed the same strategy by stating that the Copenhagen Climate Summit exposed a "a vacuum of political leadership”, - it was therefore up to the cement industry to take “a lead role in shaping the solution to this challenge...”. In other words, governments have failed, business is in control.

\section{The chicken or the egg}

The CRC period of analysis saw the emergence of a particular type of linguistic strategy whereby organisations not only attempt to shield themselves from blame, but also identify a 
range of other constituencies that also have responsibilities in relation to climate change (differentiation). In particular, during this period organisations tended to accept, to a degree, responsibility for climate change, but sought to articulate the view that such responsibility is shared among other members of the community, society and business. Moreover, by using the metaphor of the "chicken or the egg”, the linguistic technique brought into play often ensured that 'the other' was cast in the role of being the problematic partner. In this way, reports were used to build the case that organisations were doing all that they could to reduce emissions, but that their hands were tied, due to the failure or lack of commitment of other organisations or stakeholder groups. This technique was most apparent in the following narrative:

"Alternative fuels pose a classic chicken-and-egg problem - automakers can produce a range of products capable of running on fuels with varying carbon content, but the benefits are only realized if energy providers bring the fuels to market and consumers demand both the vehicle and the fuel.” (Ford, 2010; p. 146)

In this respect, we would argue that the CRC period sees organisations trying to "pass the buck" to some extent, by displacing their duty to address climate change and placing it on to other constituencies. Understood in the context of the CRC, a compulsory scheme involving organisations across different sectors and where league table of performance will be publically disclosed - this strategy not only helps propose the idea that business response to climate change is a shared responsibility, but also resolves individual organisations from bearing the full weight of any potential criticism for failing to meet required standards by obfuscating the primary location of “original sin”.

Given the benchmarking approach used in the CRC, justification framed in terms of the chicken or the egg metaphor could alleviate stakeholder pressure in some industrial sectors. 
The following statement by Rolls Royce (2010; p.9) is indicative of the problem of identifying what or where the starting point for ameliorating actions might lie:

"Electricity and heat account for the largest proportion at 36 per cent, highlighting the urgent need for this sector to adopt renewable and low-emission technologies. It is clear that if the world is to achieve a halving of carbon emissions by mid-century, the electricity supply will have to be substantially decarbonised."

BP (2010) also dispersed blame by suggesting that addressing the problem is not just a matter for BP, but "will require the efforts of governments, industry and individuals." Similarly, Motorola (2010; p.2) note, “Climate change is one of the greatest challenges of our time. Businesses, governments and consumers must take action to reduce energy use and to help build a low-carbon world”. Tesco specifically identify the customer as the main barrier to the amelioration of climate change, again, suggesting that the problem does not reside with Tesco and that initiatives for reducing climate change should be therefore directed at customers. They state:

\footnotetext{
"Climate change will only be tackled successfully if people become champions of a low-carbon lifestyle. Our role is to show customers that living greener lives can be attractive and affordable. In the UK we know that our customers' carbon footprint is around 100 times greater than Tesco's direct carbon footprint, so we have a real opportunity to tackle climate change by mobilising our customers to make small changes that add up to a big difference." (Tesco, 2010; p.28)
}

The above extracts and their analysis have led us to demonstrate that companies have employed a particular linguistic strategy as a means of displacing/deflecting their responsibilities in regard to climate change. We are not denying that companies are constrained in their ability to ameliorate climate change - for example, without the ability to supply "green fuel"; it would be difficult for car manufacturers to sell cars dependent on such fuel. Nevertheless, we have demonstrated a notable shift, during the CRC period, 
towards the use of this specific linguistic strategy. Accounting for this at a theoretical level, Sonnett (2009, p.700) draws on Bourdieu’s “field theory” to highlight how "the legitimacy of cultural representations” can be understood through the concept of symbolic capital.

For Sonnett (2009; p.700), symbolic capital includes the "cultural and linguistic resources that actors can invest for symbolic profits in the course of their position taking”. Thus, in analysing the language used by companies in the CRC period, we conclude that companies' shift towards the prevalent use of a linguistic strategy that deflects responsibility (or shifts the blame) must be an indication of its symbolic value.

\section{Discussion and Conclusions}

The aim of this study was to explore corporate communication related to climate change in the context of a voluntary and mandatory setting. Employing a context-sensitive discourse analytic approach, the study sought to link micro-level linguistic analysis (specifically, an analysis of the typical linguistic strategies of symbolic construction and modes of operation of ideology) with wider social and cultural processes. Our analysis drew attention to how companies constitute and reproduce the field in which they operate.

More specifically, we outlined how the field of climate change policy has been shaped by the economic and social capital of industry. To this end, the logic of the field of climate change policy is framed by market liberalism, with an emphasis on "economic growth" (Bernstein, 2000, p.470) and through attempts to address climate change through the

promotion of market instruments (Okerekee, 2008; Tanner and Allouche, 2011). This interpretation of the field is supported by our analysis of the social and historical context of 
the UK ETS and CRC schemes, which highlighted how both schemes were shaped by the vested interest of UK businesses, represented by the CBI. In particular, the UK ETS emerged out of a context whereby financial instruments were being considered as a means of addressing climate change (the Marshall Report), and the UK ETS itself was designed by the CBI. In keeping with the market liberal framing of the policy arena, both schemes encouraged participation and support by offering financial incentives to business. Further, the UK ETS was a voluntary initiative, consistent with a market liberal perspective

The CRC policy initiative was developed by the UK government in the context of an escalating international climate change policy agenda and the move towards the second Kyoto commitment period (Giddens, 2009; Tanner and Allouche, 2011). In line with the UK government's (as well as the EU's) commitment to carbon reduction - the CRC was introduced as a mandatory scheme. However, the CRC maintained an overall market liberal approach by instituting a cap-and-trade element, relying on self-certification and offering financial incentives (although these were eventually withdrawn).

The disclosures produced by participants in the UK ETS and CRC were not only used to provide legitimacy to the organisational response to climate change (Bebbington et al., 2008) but also served to reproduce and shape the field in which they operate. By employing linguistic strategies of symbolic construction, such as rationalization and dissimulation narrative on climate change has tended to emphasise corporate voluntarism and marketbased solutions such as emissions trading. 
Of particular relevance to this study, there was a notable shift in the linguistic strategies employed in the mandatory CRC period of analysis, whereby companies sought to displace their own responsibility to tackle climate change and shift responsibility/blame on to a range of different constituencies (differentiation). Using this type of discourse, organisations argued that their response to climate change could only succeed if their suppliers and other stakeholder groups also took responsibility.

While we acknowledged that organisations will no doubt face constraints with regard to their relationships with other stakeholders, we would also argue that the emphasis of a particular linguistic strategy must also be indicative of its symbolic value (Sonnett, 2009). In this sense, by linking our micro-level linguistic analysis with a consideration of the wider social context - we have offered an interpretation of how a shift to mandatory reporting setting might have a bearing on the linguistic strategies employed in corporate communication. One possible interpretation of why companies might have placed greater emphasis on the strategy of dissimulation during the CRC period is related to the initial intention of the scheme to utilize league tables. As noted, while organisations may resist or express doubt about the measurements used in the construction of such tables, these performance measures nevertheless represent “calculations of risk” to which organisations will try and manage (Power, 2009, p.314). Directing attention to the responsibility of other constituencies might represent one way of managing this process.

Our study contributes to the increasing understanding of how corporations position themselves vis-à-vis climate change - and how this positioning shifts in response to the socio-historical context. In particular, we have examined the linguistic strategies employed 
by participants in the voluntary UK Emissions Trading Scheme (UK ETS) and the UK Government's mandatory Carbon Reduction Commitment Energy Efficiency Scheme (CRC). In doing so, we have highlighted how, through their communicative practice, companies have helped to constitute and reproduce the structure of the field in which they operate. In this sense, we have argued that the language used by companies through their corporate communications can be viewed as both constitutive, by actively shaping the world around us "by providing conceptual guidance for actions [and] policy prescriptions" and by reproducing the logic of the field, in the interests of dominant groups within society (Andrew and Cortese, 2011; Liversey, 2002).

Such findings have clear and significant implications. As noted above, by invoking linguistic strategies that appeal to market mechanisms as a solution to climate change, the positions taken by companies in their communications contribute to the reproduction of the field of climate change policy - a field that is framed by market liberalism. But why should we rely on market mechanisms in the face of such a cataclysmic threat? As Bello (2009) and Lohman (2009) point out, markets fail - most notably, the Global Financial Crisis of 2008, and more relevant to our concerns, the failure of the European Emissions Trading Scheme (Bello, 2009; Giddens, 2009). With regard to the latter, numerous accounts of the EU ETS have noted price collapses due to the over allocation of allowances, private companies making windfall profits by passing the price of carbon credits onto consumers (even though they had been allocated free of charge), gaming, and fraud (Bello, 2009; Böhm and Dabhi, 2009; Giddens, 2009). Perhaps most importantly, the EU ETS has, at best, only had a very modest impact on emissions reductions (Laing et al., 2013). 
By highlighting the relationship between language and other social processes, and how such relations are shaped by power, our study illustrates how the linguistic strategies employed by corporations in relation to climate change can be enrolled "in the constitution and consolidation of forms of social life which lead to and perpetuate injustices and inequalities and are detrimental to the well-being of many people" (Chouliaraki and Fairclough, 2010; p. 1215). In particular, through the promotion of market mechanisms and the deflecting of responsibility on to other constituencies, corporations communications on climate change represent "particular ways of construing (representing, interpreting) particular aspects of the social process... whilst marginalizing others (Chouliaraki and Fairclough, 2010; p. 1215). The implications of our study are therefore to "point to the need for a struggle to develop... a new 'language' as a key element in building resistance” (Fairclough, 1993; p.133). 


\section{REFERENCES}

Alvesson, M. and Karreman, D. (2000), "Varieties of Discourse: On the Study of Organizations through Discourse Analysis", Human Relations, Vol. 53, No. pp. 1125-1149.

Andrew, J. and Cortese, C. (2011), "Accounting for climate change and the self-regulation of carbon disclosures", Accounting Forum, Vol. 35, No. pp. 130- 138.

Arnold, P. (1998), "The limits of postmodernism in accounting history: the decatur experience", Accounting, Organizations and Society, Vol. 23, No. 7, pp. 665-84.

Arnold, P. (1999), "From the union hall: a labour critique of the newmanufacturing and accounting regimes", Critical Perspectives on Accounting, Vol. 10, No. 4, pp. 399-423.

Banerjee, S. B. (2003), "Who Sustains Whose Development? Sustainable Development and the Reinvention of Nature", Organization Studies, Vol. 24, No. 1, pp. 143-180.

Barclays (2009), "Barclays PLC 2009 Responsible Banking Review", available at: http://group.barclays.com/Home (accessed 24.08.2011).

Bebbington, J., Kirk, E. and Larrinaga-Gonzalez, C. (2012), "The production of normativity: A comparison of reporting regimes in Spain and the UK", Accounting, Organizations and Society, Vol. 37, No. 2, pp. 78-94.

Bello, W. (2009), "Carbon Markets: A Fatal Illusion", in Böhm, S. and Dabhi, S. (Ed.), Upsetting the Offset: The Political Economy of Carbon Markets, Mayfly Books, London, pp. 5-9.

Bernstein, S. (2000), "Ideas, Social Structure and the Compromise of Liberal Environmentalism", European Journal of International Relations, Vol. 6, No. pp. 464.

Böhm, S. and Dabhi, S. (2009), "Introduction", in Böhm, S. and Dabhi, S. (Ed.), Upsetting the Offset: The Political Economy of Carbon Markets, Mayfly Books, London, pp.

Bond, P. (2011), "Climate-crisis capitalism, global environmental governance and geopolitical competition in emissions laxity", available at: http://ccs.ukzn.ac.za/files/Bond Ilrig background paper.pdf (accessed 09.07.2013).

Bourdieu, P. (Ed.)(2004a), The forms of capital, London, Routledge Falmer.

Bourdieu, P. (2004b), Science of science and reflexivity, Polity Press, Cambridge.

BP (2004), "BP sustainability report 2004", available at: http://www.bp.com/content/dam/bp/pdf/sustainability/country-reports/Sustainability_ Report_2004.pdf (accessed 14.12.2004). 
BP (2009), "Sustainable review ", available at: http://www.bp.com (accessed 12.08.2010).

BP (2010), "Sustainable review ", available at: http://www.bp.com (accessed 12.08.2010).

BritishAirways (2011), "Corporate Responsibility Report 2010/2011", available at: http://www.corporateregister.com/ (accessed 20.06.2012).

Buhr, N. and Freedman, M. (2001), "Culture, institutional factors and differences in environmental disclosure between Canada and the United States", Critical Perspectives on Accounting Vol. 12, No. pp. 293-322.

Buhr, N. and Reiter, S. (2006), "Ideology, the environment and one world view: A discourse analysis of Noranda's environmental and sustainable development reports", in Freedman, M. and Jaggi, B. (Ed.), Advances in Environmental Accounting and Management, Emerald Group Publishing, Bingley, pp. 1-48.

CarbonTrust (2005), "The UK Climate Change Programme: Potential evolution for business and the public sector", available at: http:// www.carbontrust.co.uk/publications/pages/home.aspx (accessed 05.08.2005).

Confederation of British Industry (CBI) (2011), "Make carbon reduction commitment work for business - CBI", available at: http://www.cbi.org.uk/media-centre/pressreleases/2011/03/make-carbon-reduction-commitment-work-for-business-cbioncommitment-work-for-businesses-cbi/ (accessed 09.07.2013).

Confederation of British Industry (CBI) (2012), "Replacing the CRC with effective business energy efficiency policy: CBI response to the DECC consultation on a simplified CRC energy efficiency scheme ", available at: http://www.cbi.org.uk/media/1529408/cbi_response_to_crc_consultation_-_june_2012.pdf (accessed 09.07.2013).

Chelli, M. and Gendron, Y. (2013), "Sustainability ratings and the disciplinary power of the ideology of numbers", Journal of Business Ethics, Vol. 112, No. 2, pp. 187-203.

Chouliaraki, L. and Fairclough, N. (2010), "Critical Discourse Analysis in Organizational Studies: Towards an Integrationist Methodology", Journal of Management Studies, Vol. 47, No. 6, pp. 1213-1218.

Committeeon Climate Change (2010), "The CRC Energy Efficiency Scheme - advice to Government on the second phase", Committee on Climate Change, London, pp. 32.

Criado-Jimenez, I., Fernandez-Chulian, M., Javier Husillos-Carques, F. and LarrinagaGonzalez, C. (2008), "Compliance with mandatory environmental reporting in financial statements: The case of Spain 2001-2003", Journal of Business Ethics Vol. 79, No. pp. 245-262. 
Day, R. and Woodward, T. (2004), "Disclosure of Information about Employee in the Directors Report of UK Published Financial Statements: Substantive orSymbolic?", Accounting Forum, Vol. 28, No. pp. 43-59.

de Aguiar, T.R.S. and Bebbington, J. (2014), “Global Climate Change Disclosure: Analysing the UK Emission Trading Scheme’. Accounting Forum, 38: 227-240.

de Aguiar, T. R. S. and Fearfull, A. (2010), "Global climate change and corporate disclosure: Pedagogical tools for critical accounting?", Social and Environmental Accounting Journal, Vol. 30, No. 2, pp. 64-79.

Department of Energy \& Climate Change (DECC) (2010), "Statutory Guidance: Civil penalties under the CRC Energy Efficiency Scheme Order 2010", DECC, London, pp. 11.

Department of Energy \& Climate Change (DECC) (2011), "Simplifying the CRC Energy Efficiency Scheme: Next Steps", available at: http://www.decc.gov.uk/en/content/cms/ emissions/crc_efficiency/crc_efficiency.aspx (accessed 08.08.2011).

Department of Energy \& Climate Change (DECC) (2012), "Consultation on simplifying the CRC Energy Efficiency Scheme: Government Response", The Stationery Office Limited, London, pp. 1-74.

Deegan, C. (2002), "The legitimising effect of social and environmental disclosures - a theoretical foundation", Accounting, Auditing \& Accountability Journal, Vol. 15, No. 3, pp. 282-311.

Deegan, C. and Rankin, M. (1997), "The materiality of environmental information to users of annual reports", Accounting, Auditing and Accountability Journal, Vol. 10, No. 4, pp. 562-583.

Department of Trade and Industry (DTI) (2006), "The energy challenge energy review report 2006", available at: (accessed 26.09.2005).

ENDS Environmental Data Service (2009), "The Carbon Reduction Commitment", available at: http://www.endsreport.com (accessed 04.08.2011).

Environmental Agency (2013), "CRC Energy Efficiency Scheme Annual Report Publication", available at: http://www.doeni.gov.uk/crc_energy_efficiency_scheme_ environment_agency_annual_report.pdf (accessed 26.10.2014).

Environmental Agency (2014), "CRC Energy Efficiency Scheme Annual Report Publication 2013/2014", available at: https://www.gov.uk/government/publications/crcannual-report-publication-2013-to-2014 (accessed 22.03.2015).

ENVIROS Consulting (2006), Appraisal of years 1-4 of the UK Emissions Trading Scheme, Enviros Consulting Limited, London. 
Fairclough, N. (1992), "Discourse and Text: Linguistic and Intertextual Analysis within Discourse Analysis", Discourse Society, Vol. 3, No. 2, pp. 193-217.

Fairclough, N. (1993), "Critical Discourse Analysis and the Marketization of Public Discourse: The Universities", Discourse Society, Vol. 4, No. 2, pp. 133-168.

Ferguson, H. L., Collison, D., Power, D. and Stevenson, L. (2007), "Exploring accounting educators' perceptions of theemphasis given to different stakeholders in introductory textbooks", Accounting Forum, Vol. 31, No. 2, pp. 113-27.

Ferguson, J. (2007), "Analysing accounting discourse: avoiding the "fallacy of internalism”", Accounting, Auditing \& Accountability Journal, Vol. 20, No. 6, pp. 912-934.

Ferguson, J., Collison, D., Power, D. and Stevenson, L. (2009), "Constructing meaning in the service of power: An analysis of the typical modes of ideology in accounting textbooks", Critical Perspectives on Accounting, Vol. 20, No. pp. 896-909.

Ford (2004), "2003/04 Corporate citizenship report: Our principles, progress and performance", available at: http://www.ford.com (accessed 25.05.2006).

Ford (2010), "2009/2010 Blueprint for sustainability: The future at work", available at: http://corporate.ford.com/doc/sr09-blueprint-summary.pdf (accessed 24.08.2011).

Francis, J. (1994), "Auditing, hermeneutics and subjectivity", Accounting, Organizations and Society Vol. 19, No. 3, pp. 235-71.

Freedman, M. and Jaggi, B. (2005), "Global warming, commitment to the Kyoto protocol, and accounting disclosures by the largest global public firms from polluting industries", The International Journal of Accounting, Vol. 40, No. pp. 215-232.

Giddens, A. (2009), The politics of climate change, Polity Press, Cambridge.

Grant, D., Hardy, C., Oswick, C. and Putnam, L. (2004), The Sage handbook of organizational discourse., Sage, London.

Gray, R., Adams, C. and Owen, D. (2014), Accountability, social responsibility and sustainability: Accounting for society and the environment, Pearson, Harlow.

Gray, R., Kouhy, R. and Lavers, S. (1995), "Methodological themes: Constructing a research database of social and environmental reporting by UK companies", Accounting, Auditing and Accountability Journal, Vol. 8, No. 2, pp. 78-101.

Grenfell, M. and James, D. (1998), Bourdieu and education: Acts of practical theory, UK Falmer Press, London.

Grubb, M., Vrolijk, C. and Brack, D. (1999), The Kyoto Protocol: A guide and Assessment, Royal Institute of International Affairs, Washington. 
Hackston, D. and Milne, M. J. (1996), "Some determinants of disclosures in NZ companies", Accounting, Auditing and Accountability Journal, Vol. 9, No. 1, pp. 77-108.

HM Government (2006), "Climate Change: The UK programme 2006", available at: (accessed 24.01.2007).

HM Treasury (2010), "Spending review 2010", The Stationery Office Limited, London, pp. 105.

Klein, N. (2007), The Shock Doctrine: The Rise of Disaster Capitalism, Allen Lane, London.

Kolk, A., Levy, D. and Pinkse, J. (2008), "Corporate responses in an emerging climate regime: The institutionalization and commensuration of carbon disclosure", European Accounting Review, Vol. 17, No. 4, pp. 719-745.

Kolk, A. and Pinkse, J. (2004), "Market strategies for climate change", European Management Journal, Vol. 22, No. 3, pp. 304-314.

Krippendorff, K. (1980), Content Analysis: An introduction to its methodology, Sage, London.

Lafarge (2002), "Building value in the long run: 2002 sustainability report", available at: http://www.lafarge.com (accessed 21.12.2004).

Lafarge (2010), "2009 Sustainability report", available at: http://www.corporateregister.com/ (accessed 20.06.2012).

Laine, M. (2005), "Meanings of the term 'sustainable development' in Finnish corporate disclosures", Accounting Forum, Vol. 29, No. pp. 395-413.

Laine, M. (2009), "Ensuring legitimacy through rhetorical changes?: A longitudinal interpretation of the environmental disclosures of a leading Finnish chemical company", Accounting, Auditing \& Accountability Journal, Vol. 22, No. 7, pp. 1029-1054.

Laine, M. (2010), "Towards Sustaining the Status Quo: Business Talk of Sustainability in Finnish Corporate Disclosures 1987-2005", European Accounting Review, Vol. 19, No. 2, pp. 247-274.

Laing, T., Sato, M., Grubb, M. and Comberti, C. (2013), "Assessing the effectiveness of the EU Emissions Trading System", available at: http://www.lse.ac.uk/GranthamInstitute/wpcontent/uploads/2014/02/WP106-effectiveness-eu-emissions-trading-system.pdf (accessed 21.03.2015). 
Levy, D. and Egan, D. (2003), "A neo-Gramscian approach to corporate political strategy: Conflict and accommodation in the climate change negotiations", Journal of Management Studies, Vol. 40, No. 4, pp. 804-829.

Liversey, S. M. (2002), "The discourse of the middle ground: Citizen shell commits to sustainable development", Management Communication Quarterly, Vol. 15, No. 3, pp. 313-349.

Lodhia, S. and Jacobs, K. (2013), "The practice turn in environmental reporting: A study into current practices in two Australian commonwealth departments", Accounting, Auditing \& Accountability Journal, Vol. 26, No. 4, pp. 595-615.

Lohman, L. (2009), "Neoliberalism and the Calculable World: The Rise of Carbon Trading", in Böhm, S. and Dabhi, S. (Ed.), Upsetting the Offset: The Political Economy of Carbon Markets, Mayfly Books, London, pp. 25-41.

Mäkelä, H. and Laine, M. (2011), "A CEO with many messages: Comparing the ideological representations provided by different corporate reports", Accounting Forum, Vol. 35, No. 4, pp. 217-231.

Marshall, L. (1998), Economic Instruments and the Business Use of Energy, Government Task Force on the Industrial Use of energy, London.

McNicholas, P. and Windsor, C. (2011), "Can the financialised atmosphere be effectively regulated and accounted for?", Accounting, Auditing \& Accountability Journal, Vol. 24, No. 8, pp. 1071-1096.

Milne, M. J. and Adler, R. W. (1999), "Exploring the reliability of social and environmental disclosures content analysis", Accounting, Auditing and Accountability Journal, Vol. 12, No. 2, pp. 237-256.

Milne, M. J., Kearins, K. and Walton, S. (2006), "Creating Adventures in Wonderland: The Journey Metaphor and Environmental Sustainability", Organization, Vol. 13, No. 6, pp. 801-839.

Milne, M. J., Tregidga, H. and Walton, S. (2009), "Words not actions! The ideological role of sustainable development reporting", Accounting, Auditing \& Accountability Journal, Vol. 22, No. 8, pp. 1211-1257.

Motorola (2010), "2009 Motorola corporate reponsibility sumary report", available at: http://www.corporateregister.com/ (accessed 20.06.2012).

National Audit Office (NAO) (2004), "The UK Emissions Trading Scheme: A New Way to Combat Climate Change", available at: http://www.nao.org.uk (accessed 09.12.2004). 
National Audit Office (NAO) (2012), "The CRC Energy Efficiency Scheme", available at: http://www.nao.org.uk/wp-content/uploads/2012/08/ECCC_briefing_CRC_scheme.pdf (accessed 09.07.2013).

NERA Economic Consulting and ENVIROS Consulting (2006), "Energy efficiency and trading part II: Options for implementation of a new mandatory UK emissions trading scheme", DEFRA, London, pp. 158.

Ney, M. (2008), "Undestanding business participation in the UK emissions trading scheme: Dimensions of choices and influences on market development", in Antes, R., Hansjurgens, B. and Letmathe, P. (Ed.), Emissions trading:Institutional design, decision making and corporate strategies, Springer Science+Business Media, New York, pp. 235-246.

Nyberg, D. and Wright, C. (2012), "Justifying business responses to climate change: discursive strategies of similarity and difference", Environment and Planning A, Vol. 44, No. 8, pp. 1819-1835.

Nye, M. and Owens, S. (2008), "Creating the UK Emission Trading Scheme: Motives and Symbolic Politics", European Environment, Vol. 18, No. pp. 1-15.

Oakes, L. S., Considine, J. and Gould, S. (1994), "Counting Health Care Costs in the United States: A Hermeneutical Study of Cost Benefit Research", Accounting, Auditing \& Accountability Journal, Vol. 7, No. 3, pp. 18-49.

Oakes, L. S., Townley, B. and Cooper, D. C. (1998), "Business planing as pedagogy: Language and control in a changing institutional field", Administrative Science Quarterly, Vol. 43, No. pp. 257-292.

Okereke, C. (2008), "Equity norms in global environmental governance", Global Environmental Politics, Vol. 8, No. 3, pp. 25-50.

Porter, M. E. and Kramer, M. R. (2011), "The Big Idea: Creating Shared Value", available at: http://www.professoralanross.com/wp-content/uploads/2011/03/The-Big-Idea-Creating Shared-Value-Harvard-Business-Review.pdf (accessed 22.12.2011).

Porter, M. E. and Van der Linde, C. (1995a), "Green and Competitive", Havard Business Review, Vol. 73, No. 5, pp. 120-134.

Porter, M. E. and Van der Linde, C. (1995b), "Toward a new conception of the environment-competitiveness relationship", Journal of Economic Perspectives, Vol. 9, No. 4, pp. 97-118.

Power, M., Scheytt, T., Soin, K. and Sahlin, K. (2009), "Reputational Risk as a Logic of Organizing in Late Modernity", Organization Studies, Vol. 30, No. 2/3, pp. 301-324. 
Rolls Royce (2010), "Powering a better world: Health, Safety and Environment Report 2010", available at: http://www.rolls-royce.com/Images/hsereport_2010_tcm92-23086.pdf (accessed 24.08.2011).

Shell (2001), "People, planet, profits: The Shell report 2001", available at: http://www.shell.com (accessed 28.05.2006).

Shell (2003), "Meeting the energy challenge - our progress in contributing to sustainable development", available at: http://www.shell.com/ (accessed 28.05.2006).

Sonnett, J. (2009), "Climates of risk: A field analysis of global climate change in US media discourse 1997-2004", Public Understanding of Science, Vol. 19, No. 6, pp. 698-716.

Spence, C. (2007), "Social and environmental reporting and hegemonic discourse", Accounting, Auditing \& Accountability Journal, Vol. 20, No. 6, pp. 855-882.

Spence, C. (2009), "Social and environmental reporting and the corporate ego", Business Strategy and the Environment, Vol. 18, No. 4, pp. 254-265.

Spence, C. and Thomson, I. (2009), "Resonance tropes in corporate philanthropy discourse", Business Ethics: A European Review, Vol. 18, No. 4, pp. 372-388.

Tanner, T. and Allouche, J. (2011), "Towards a new political economy of climate change and development", IDS Bulletin, Vol. 42, No. 3, pp. 1-14.

Tesco (2009), "Corporate responsibility report 2010", available at: http://cr2010.tescoplc.com/ (accessed 24.08.2011).

Tesco (2010), "Corporate responsibility report 2011", available at: http://www.corporateregister.com/ (accessed 20.06.2012).

Thompson, J. B. (1990), Ideology and Modern Culture, Stanford University Press, Stanford, CA.

Tregidga, H., Kearins, K. and Milne, M. (2013), "The politics of knowing 'organizational sustainable development", Organization \& Environment, Vol. 26, No. 1, pp. 102-129.

Tregidga, H. and Milne, M. J. (2006), "From sustainable management to sustainable development: a longitudinal analysis of a leading New Zealand environmental reporter", Business Strategy and the Environment, Vol. 15, No. pp. 219-241.

Vaara, E., Sorsa, V. and Pälli, P. (2010), "On the force potential of strategy texts: a critical discourse analysis of a strategic plan and its power effects in a city organization", Organization, Vol. 17, No. pp. 685. 
Von Malmborg, F. and Strachan, P. A. (2005), "Climate policy, ecological modernization and the UK emission trading scheme", European Environment, Vol. 15, No. pp. 143-160.

World Commission for Economic Development (WCED) (1987), Our common future, Oxford University Press, Oxford. 
Table 1: Modes and Associated Strategies of Ideology (Thompson, 1990)

\begin{tabular}{|l|l|l|}
\hline $\begin{array}{l}\text { Mode of operation } \\
\text { of ideology }\end{array}$ & \multicolumn{1}{|c|}{$\begin{array}{c}\text { Linguistic } \\
\text { Strategy }\end{array}$} & \multicolumn{1}{c|}{ Explanation } \\
\hline \multirow{4}{*}{ Legitimation } & Rationalization & Justify or rationalize social relations \\
\cline { 2 - 3 } & Universalization & Argues that institutional relations that serve a few groups are benefiting everyone \\
\cline { 2 - 3 } & Narrativization & Current social relations are located within traditions and stories from the past \\
\hline Dissimulation & Displacement & Using a term that would normally refer to something else \\
\cline { 2 - 3 } & Euphemization & Shift in descriptive language that gives social relations a positive “spin” \\
\cline { 2 - 3 } & Trope & Includes synecdoche, metonymy and metaphor \\
\hline Fragmentation & Standardization & Standardization of language and symbols to create a union of individuals or groups \\
\cline { 2 - 3 } & $\begin{array}{l}\text { Symbolization of } \\
\text { Unity }\end{array}$ & Adoption of a shared set of symbols to create a collective identity among groups \\
& Differentiation & Emphasis of differences between groups \\
\cline { 2 - 3 } & $\begin{array}{l}\text { Expurgation of } \\
\text { the other }\end{array}$ & Creating a common enemy - to unite people in opposition \\
\hline Reification & Naturalization & Presenting situations as natural and as the outcome of a natural historical process \\
\cline { 2 - 3 } & Eternalization & Portraying situations without their historical background \\
\cline { 2 - 3 } & Nominalization & Actors and action within a sentence are turned into nouns \\
\hline
\end{tabular}


Table 2: Characteristics of companies in both schemes - UK ETS and CRC

\begin{tabular}{|c|c|c|c|c|}
\hline \multicolumn{2}{|r|}{$\begin{array}{c}\text { UK ETS } \\
\text { DIRECT PARTICIPANTS (I) }\end{array}$} & \multirow{2}{*}{$\begin{array}{c}\text { LEGAL } \\
\text { FORM } \\
\text { Private }\end{array}$} & \multirow{2}{*}{$\begin{array}{c}\begin{array}{c}\text { ORIGIN } \\
\text { COUNTRY }\end{array} \\
\text { US }\end{array}$} & \multirow{2}{*}{$\begin{array}{c}\text { INDUSTRY SECTOR (II) } \\
\text { General retailers }\end{array}$} \\
\hline 1 & Asda Stores Ltd & & & \\
\hline 2 & Barclays Bank plc & Public & UK & Bank \\
\hline 3 & BP plc & Public & UK & Oil \& gas producers \\
\hline 4 & British Airways plc & Public & UK & Travel \& leisure \\
\hline 5 & British Sugar plc & Public & UK & Food producers \\
\hline 6 & Dalkia Energy plc & Public & France & Gas, water \& multiutilities \\
\hline 7 & Dalkia Utilities Servicies plc & Public & France & Gas, water \& multiutilities \\
\hline 8 & Invista UK Ltd & Private & US & Chemical \\
\hline 9 & Ford Motor Company Ltd & Private & US & Automobiles \& parts \\
\hline 10 & General Domestic Appliances Ltd & Private & Italty & Manufacturing of electric domestic appliances \\
\hline 11 & GKN (UK) plc & Private & UK & Automobiles \& parts \\
\hline 12 & Imerys Minerals Ltd & Private & France & Construction \&materials \\
\hline 13 & Ineos Fluor Ltd & Private & UK & Manufacture of industrial gases \\
\hline 14 & Lafarge plc & Private & France & Construction \& materials \\
\hline 15 & Land Securities plc & Public & UK & Real state \& development \\
\hline 16 & Lend Lease R. E. I. Services Ltd & Private & Australia & Real state and development \\
\hline 17 & Marks \& Spencer plc & Public & UK & General retailers \\
\hline 18 & Motorola GTSS & Private & US & Technology, hardware \& equipment \\
\hline 19 & Rhodia Organique Fine Ltd & Private & France & Manufacturing or other organic basic chemical \\
\hline 20 & Rolls-Royce plc & Public & UK & Aerospace \& defense \\
\hline 21 & Royal Ordnance plc & Public & UK & Aerospace \& defense \\
\hline 22 & Shell UK Ltd & Private & UK & Oil \& gas producers \\
\hline 23 & Tesco Stores Ltd & Private & UK & Food and drug retailers \\
\hline 24 & UK Coal Mining Ltd & Private & UK & Mining and agglomeration of hard coal \\
\hline
\end{tabular}

Sources: NAO (2004), CRC League Table 2010/11, FTSE 500 ranking 2006 (http://www.ft.com/reports/ft5002006/), Amadeus database (NACE code) and Companies' reports. Note: Universities, Kirklees Metropolitan Council and Natural History Museum were excluded since the scope of this paper concentrates on companies. Companies that participated in the UK ETS only were also excluded (Budweiser, Dana, First Hydro, General Domestic Appliances, General Domestic Appliances and Somerfield). 
Table 3: Comparison between UK ETS and CRC

\begin{tabular}{|c|c|c|}
\hline Characteristics & UK ETS & CRC \\
\hline Nature & Voluntary & Mandatory \\
\hline Outcomes expected & $\begin{array}{l}\text { - Create cost-effective greenhouse gases emissions } \\
\text { reductions; } \\
\text { - Prepare organisations for participating in emissions } \\
\text { trading, especially the EU ETS; } \\
\text { - Establish an emissions trading centre in London. }\end{array}$ & $\begin{array}{l}\text { - Improve energy efficiency and cut emissions in non- } \\
\text { energy intensive large public and private } \\
\text { organisations; } \\
\text { - It was designed to not include emissions covered by } \\
\text { EU ETS and Climate Change Agreements. }\end{array}$ \\
\hline Emissions reductions & $\begin{array}{l}\text { Target to achieve } 4.64 \text { million tonnes of emission } \\
\text { reduction. Emissions reductions included the six } \\
\text { greenhouse gases regulated under the Kyoto Protocol. }\end{array}$ & $\begin{array}{l}\text { Target to reduce non-traded emissions by17 million } \\
\text { tonnes by } 2027 .\end{array}$ \\
\hline Who designed it? & $\begin{array}{l}\text { UK Emissions Trading Group, which was formed by the } \\
\text { Confederation of Business Industry (CBI) and the } \\
\text { Advisory Council for Business and Environment. }\end{array}$ & The UK Government based on public consultation. \\
\hline $\begin{array}{l}\text { Number of organisations } \\
\text { involved }\end{array}$ & $\begin{array}{l}32 \text { companies and other organisations - referred to as } \\
\text { "direct participants" }\end{array}$ & $\begin{array}{l}\text { Designed for 3,000-4,000 organisations. Reporting } \\
\text { participants in the year 2013/14 accounted for 2,039. }\end{array}$ \\
\hline Operational & Cap-and-trade scheme & $\begin{array}{l}\text { - Cap-and-trade scheme; } \\
\text { - Disclosure of participants' energy use and emissions } \\
\text { (i). }\end{array}$ \\
\hline Verification/certification & $\begin{array}{l}\text { An accredited verifier was required to confirm any claimed } \\
\text { over-achievement. }\end{array}$ & No external verification required \\
\hline Incentives & $\begin{array}{l}£ 215 \text { million was distributed among participants as } \\
\text { incentive if they met their annual targets. }\end{array}$ & $\begin{array}{l}\text { Reputational, behavioural and financial drivers (e.g. via } \\
\text { cap-and-trade scheme). }\end{array}$ \\
\hline Penalties & No penalties were implemented. & Financial and civil penalties. \\
\hline Period & 5 years (from 2002 to 2006 ). & $\begin{array}{l}\text { - Phase 1: } 1 \text { April } 2010 \text { to } 31 \text { March 2014; } \\
\text { - Phase 2:1 April } 2014 \text { to } 31 \text { March 2019; } \\
\text { - Four further phases: five years each, commencing in } \\
\text { April 2019. }\end{array}$ \\
\hline Criticisms & $\begin{array}{l}\text { - Economic incentives was the main motivation; } \\
\text { - Easy targets to be achieved by participants. }\end{array}$ & $\begin{array}{l}\text { - Overlaps with EU ETS compromising emissions } \\
\text { reductions; } \\
\text { • Complicated to operate. }\end{array}$ \\
\hline
\end{tabular}

Sources: ENVIROS, 2006; NERA,2004; NAO, 2004, 2012; Committee on Climate Change, 2010; DECC, 2010, 2011, 2012 and Environmental Agency, 2013 ; 2014.

(i) League table was abolished. Now, there will be only disclosure on energy use and emissions. A summary on the main changes on CRC that occurred in Dec/12 can be found at https://www.gov.uk/government/policies/reducing-demand-for-energy-from-industry-businesses-and-the-public-sector--2/supporting-pages/crc-energy-efficiency-scheme 
Table 4: Reports analysed - Descriptive statistics

\begin{tabular}{|l|r|r|}
\cline { 2 - 3 } \multicolumn{1}{c|}{} & UK ETS & \multicolumn{1}{c|}{ CRC } \\
\hline Number of reports from companies that participated in both schemes & 63 & 36 \\
\hline Number of reports where linguistic strategies were identified & 25 & 31 \\
\hline Average length of reports (pages) & 48 & 81 \\
\hline Report with lowest number of pages & 9 & 12 \\
\hline Report with highest number of pages & 103 & 518 \\
\hline Average number of pages where linguistic strategies were identified & 0.08 & 0.38 \\
\hline
\end{tabular}

Table 5: Linguistic strategies incidence

\begin{tabular}{|c|c|c|c|c|c|}
\hline \multirow{2}{*}{ Mode of operation of ideology } & \multirow{2}{*}{ Linguistic Strategy } & \multicolumn{2}{|c|}{ Page number (i) } & \multicolumn{2}{|c|}{ Percentage (ii) } \\
\hline & & UK ETS & CRC & UK ETS & CRC \\
\hline \multirow{3}{*}{ Legitimation } & 1 Rationalization & 0.64 & 2.48 & $32 \%$ & $21 \%$ \\
\hline & 2 Universalization & 0.06 & 1.67 & $3 \%$ & $14 \%$ \\
\hline & 3 Narrativization & 0.02 & 0.69 & $1 \%$ & $6 \%$ \\
\hline \multirow{3}{*}{ Dissimulation } & 4 Displacement & 0.00 & 0.00 & $0 \%$ & $0 \%$ \\
\hline & 5 Euphemization & 0.00 & 0.21 & $0 \%$ & $2 \%$ \\
\hline & 6 Trope & 0.00 & 0.07 & $0 \%$ & $1 \%$ \\
\hline \multirow{2}{*}{ Unification } & 7 Standardization & 0.03 & 0.94 & $2 \%$ & $8 \%$ \\
\hline & 8 Symbolization of Unity & 0.23 & 0.72 & $12 \%$ & $6 \%$ \\
\hline \multirow{2}{*}{ Fragmentation } & 9 Differentiation & 0.48 & 3.63 & $24 \%$ & $31 \%$ \\
\hline & 10 Expurgation of the other & 0.52 & 1.35 & $26 \%$ & $11 \%$ \\
\hline \multirow{3}{*}{ Reification } & 11 Naturalization & 0.00 & 0.00 & $0 \%$ & $0 \%$ \\
\hline & 12 Eternalization & 0.00 & 0.00 & $0 \%$ & $0 \%$ \\
\hline & 13 Nominalization & 0.00 & 0.00 & $0 \%$ & $0 \%$ \\
\hline
\end{tabular}

(i) Number of pages disclosed per linguistic strategy.

(ii) Occurrence of each linguistic strategy as a \% of the total linguistics strategies in each scheme during the period analysed. 


\section{Appendix 1: List of abbreviations}

\begin{tabular}{|l|l|}
\hline AWG-KP & $\begin{array}{l}\text { Ad Hoc Working Group on Further Commitments for Annex I Parties } \\
\text { under the Kyoto Protocol }\end{array}$ \\
\hline AWG-LCA & Ad Hoc Working Group on Long-term Cooperative Action \\
\hline CBI & Confederation of British Industry \\
\hline CRC & Carbon Reduction Commitment Energy Efficiency Scheme \\
\hline DECC & Department of Energy and Climate Change \\
\hline DTI & Department of Trading and Industry \\
\hline GHG & Greenhouse gas \\
\hline IPCC & International Panel on Climate Change \\
\hline NAO & National Audit Office \\
\hline UK ETS & UK Emissions Trading Scheme \\
\hline UN FCCC & UN Framework Convention of Climate Change \\
\hline UNEP & United Nations Environment Programme \\
\hline WMO & World Meteorological Organisation \\
\hline
\end{tabular}

